\title{
Tree species effects on understory forage productivity and microclimate in a silvopasture of the Southeastern USA
}

\author{
Miguel S. Castillo ${ }^{\mathrm{a}, *}$, Francesco Tiezzi ${ }^{\mathrm{b}}$, Alan J. Franzluebbers ${ }^{\mathrm{c}}$ \\ ${ }^{\text {a }}$ Crop and Soil Sciences Department, North Carolina State University, Raleigh, NC, 27695, United States \\ ${ }^{\mathrm{b}}$ Animal Science Department, North Carolina State University, Raleigh, NC, 27695, United States \\ ' USDA-Agricultural Research Service, Raleigh, NC, 27695, United States
}

\section{A R T I C L E I N F O}

Keywords:

Silvopastures

Agroforestry

Forages

\begin{abstract}
A B S T R A C T
Ecosystem services provided by silvopastoral systems are mediated by specific management practices, environmental conditions, and overall design of the system. We hypothesized that selection of tree species affects understory forage nutritive value and productivity, light/shade environment, and microclimate. The silvopastoral system was located at the Center for Environmental Farming Systems in Goldsboro, North Carolina, USA. Three overstory tree-species were Pinus palustris (PP; longleaf pine), Pinus taeda (PT; lobloblly pine), and Quercus pagoda (QP; cherrybark oak). The understory forage component consisted of a four-way mixture of native warmseason grasses [big bluestem (Andropogon gerardii, 'Eastern', KY origin), eastern gamagrass (Tripsacum dactyloides, MO origin), indiangrass (Sorghastrum nutans, 'NC ecotype'), and switchgrass (Panicum virgatum, 'Alamo')]. The experimental design was an RCBD with 3 replicates. There was no effect of seedbed preparation (till versus no-till) on forage establishment. Understory dry matter yield, crude protein and total digestible nutrient concentrations of the harvested forage were not affected by tree species, with the exception at the 3.5 south sampling point. Overstory effects on microclimate variables were not different among tree-species, but were more noticeable during the daytime of the summer months, and were at the most 1-degree point for temperature and temperature-humidity index and 3 points for relative humidity. The silvopasture design in our study provided year-round shade by the tree-component, with varying levels of shade (ranging from 90 to $6 \%$ of incident photosynthetic active radiation) due to geographic location, tree species, and season. Our results describe and highlight the potential of trees in a silvopasture design in the southeastern USA to mitigate changes in temperature, humidity, the temperature-humidity index, and forage productivity and as a function of tree species and at different distance from the trees.
\end{abstract}

\section{Introduction}

Silvopasture systems are characterized by the intentional integration and management of trees, forages, and livestock. They have been broadly accepted as an integrated approach to sustainable land management with potential to enhance ecosystem services in a multifunctional working space (Jose, 2009; Peters et al., 2013) while providing options to mitigate and adapt to climate change (Lawson et al., 2018; Rosenstock et al., 2019). However, the potential of silvopastures to deliver ecosystem services is directly related to the interaction of its components within a specific environment. Consequently, synergies and tradeoffs are influenced by specific management decisions (Bennet et al., 2009; Jose et al., 2019; Power, 2010; Sollenberger et al., 2019).

There are multiple reports, including research articles and extension manuals, of the extent to which ecosystems services are improved by silvopastures compared to tree-less pastures in the tropics. Such review is beyond the scope of this article and we refer the reader to Dagang and Nair (2003); Peters et al. (2013); Dubeux et al. (2017); Villanueva et al. (2018), and Mauricio et al. (2018) as a starting point. In sub-tropical and temperate environments, such as in the USA, silvopastures are somewhat understudied but the body of literature is rapidly growing (Jose, 2009; Jose and Dollinger, 2019; Dold et al., 2019; USDA, 2017).

In addition to storing carbon in biomass and soils and reducing carbon dioxide loads in the atmosphere which contribute to mitigate the effects of climate change (Kim et al., 2016; Verchot et al., 2007), one of the regulating services attributed to the presence of trees in silvopastures is the potential to affect microclimate and mitigate heat stress for grazing livestock; specifically, through shifts in understory air temperature, humidity, and provision of shade and shelter for livestock. Climate change is a threat to livestock production because of potential

\footnotetext{
* Corresponding author at: 2413 Williams Hall, Crop and Soil Sciences Depart., North Carolina State University, United States.

E-mail address: mscastil@ncsu.edu (M.S. Castillo).
} 


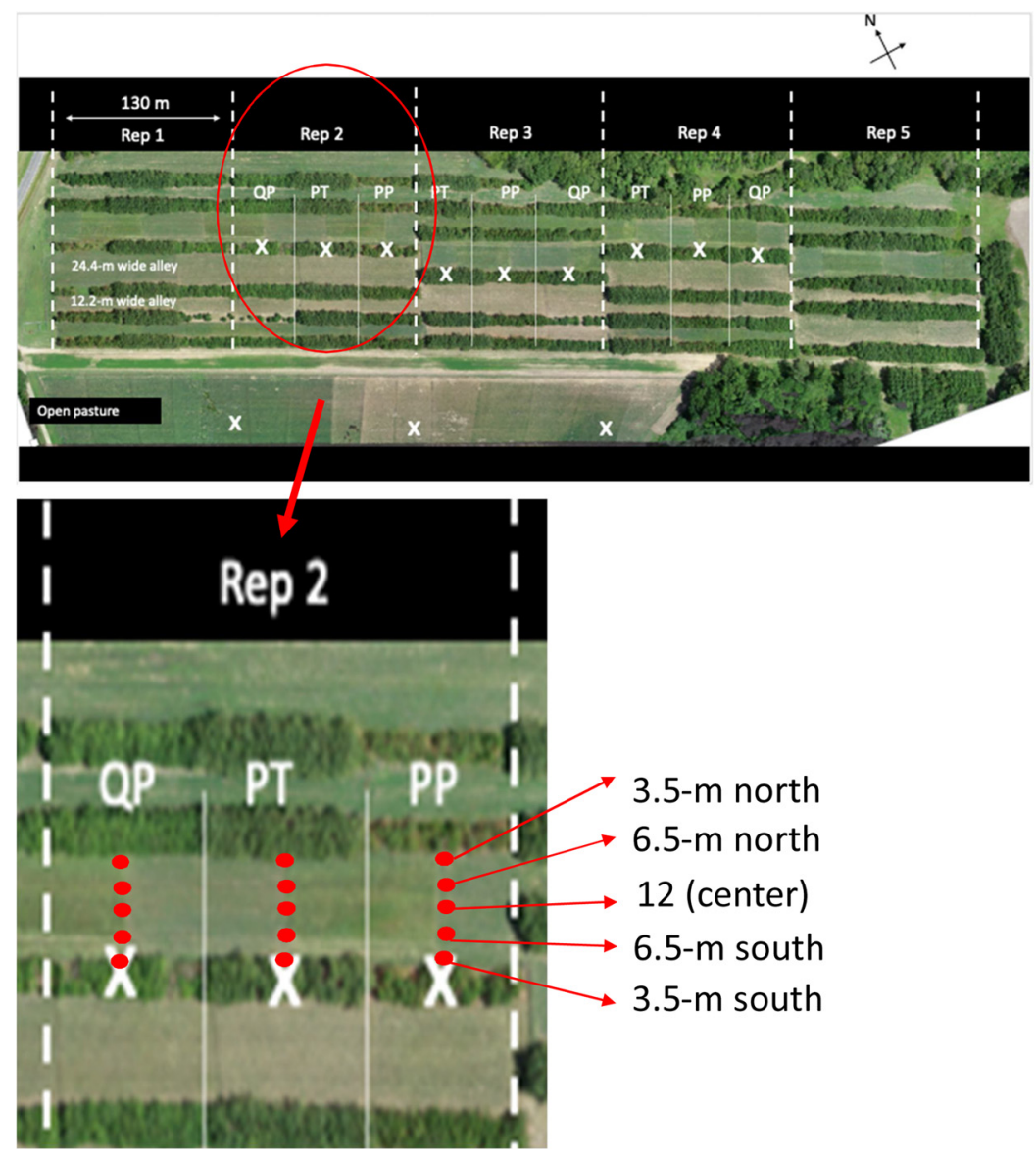

Fig. 1. Field layout of trees ( $\mathrm{PP}=$ Pinus palustris; $\mathrm{PT}=$ Pinus taeda; $\mathrm{QP}=$ Quercus pagoda), alleys (12- and 24-m wide), and location of temperature-humidity sensors ("X") at silvopasture and open-pasture in Goldsboro, NC. Rep = replicate. The red dots in the zoomed-in figure show the location and labeling of sampling points. (For interpretation of the references to colour in this figure legend, the reader is referred to the web version of this article). negative effects on quality of feed crop and forage, water availability, animal and milk production, livestock diseases, animal reproduction, and biodiversity (Rojas-Downing et al., 2017). In the dominantly timber-producing region of the southeastern USA, Karki and Goodman (2013), 2015 reported differences in microclimate for silvopastures versus open-pastures in Florida [mature loblolly-pine - bahiagrass (Paspalum notatum Flugge system] and Georgia (a young longleaf-pinebahiagrass system). The temperature-humidity index (THI), an index that combines air temperature $\left({ }^{\circ} \mathrm{F}\right)$ and relative humidity (\%), has been historically used as a measure of thermal comfort for livestock. Dairy livestock productivity may be affected when a THI threshold of 72 is reached (Igono, et al., 1992; Ravagnolo et al., 2000) resulting in economic losses (St-Pierre et al., 2003); however, threshold vary by type of livestock (Nardone et al., 2006) and exposure time (West, 2002). In the southeastern USA, THI $\geq 72$ could potentially be reached for at least about a third of the year ( $\sim 100$ to 150 days). Thorough accounting of heat stress would require weather information from the farm (as opposed to regional weather stations), thus accounting for length and strength of the heat period and information on the existence and use of heat-management measures (Ravagnolo et al., 2000). The aforementioned statement is of particular importance to capture the potential benefits of silvopastoral systems.

Shade in general, and specifically provided by trees, is considered to be essential to maintain high levels of livestock production and reproduction (Karki and Goodman, 2010). Shade also alters livestock behavior (Tucker et al., 2008), and reduces stress and even death, particularly in the southern USA (Armstrong, 1994; Kendall et al., 2006; Karki and Goodman, 2010). Under feedlot conditions, artificial shade was more effective than misting to mitigate physiological and behavioral stress of beef cattle (Mitlöhner et al., 2020). However, high level of shade in a silvopasture can have negative effects on understory forage production and subsequently lower animal responses, especially for species with the C4 photosynthetic pathway such as native warmseason grasses (Kephart et al., 1992; Lin et al., 1999; Neel et al., 2007). In the southeast USA, utilization of native warm-season grasses can complement and improve overall productivity of traditional tall fescue ([Lolium arundinaceum (Schreb.) Darbysh.] pasture-based livestock systems (Burns et al., 1984; USDA, 2018; Sanderson and Burns, 2010; Tracy et al., 2010); however, there is limited information in silvopastoral settings.

Differences in microclimate between silvopastures and tree-less pastures, and the extent of influence on understory plant responses, depend on the timing of the effects and the phenology of the trees and the crop (Lawson et al., 2019). In addition, we hypothesized that tree species affect understory microclimate and plant responses. Using a silvopastoral system with three tree species (two evergreen and one deciduous), the objectives of our experiment were to test the effect of tree species at different distances to the tree line on i) understory forage dry matter yield and ii) nutritive value and iii) to estimate the mitigation potential of different tree species on the understory microclimate (direct sunlight at solar noon, air temperature, humidity, and THI) at different times in the year.

\section{Materials and methods}

\subsection{Experimental site}

The experimental site was located in Goldsboro, North Carolina $\left(35^{\circ} 22^{\prime} \mathrm{N} ; 78^{\circ} 2^{\prime} \mathrm{W}\right)$ on the Coastal Plain resource area of the eastern USA. Detailed description of the site and initial overall project objectives were provided by Cubbage et al. (2012), soil texture and soilcarbon parameters were reported by Deiss et al. (2017), and greenhouse gas emissions were reported by Franzluebbers et al. (2017). The agroforestry site was established in 2007, occupying approximately a 7-ha 

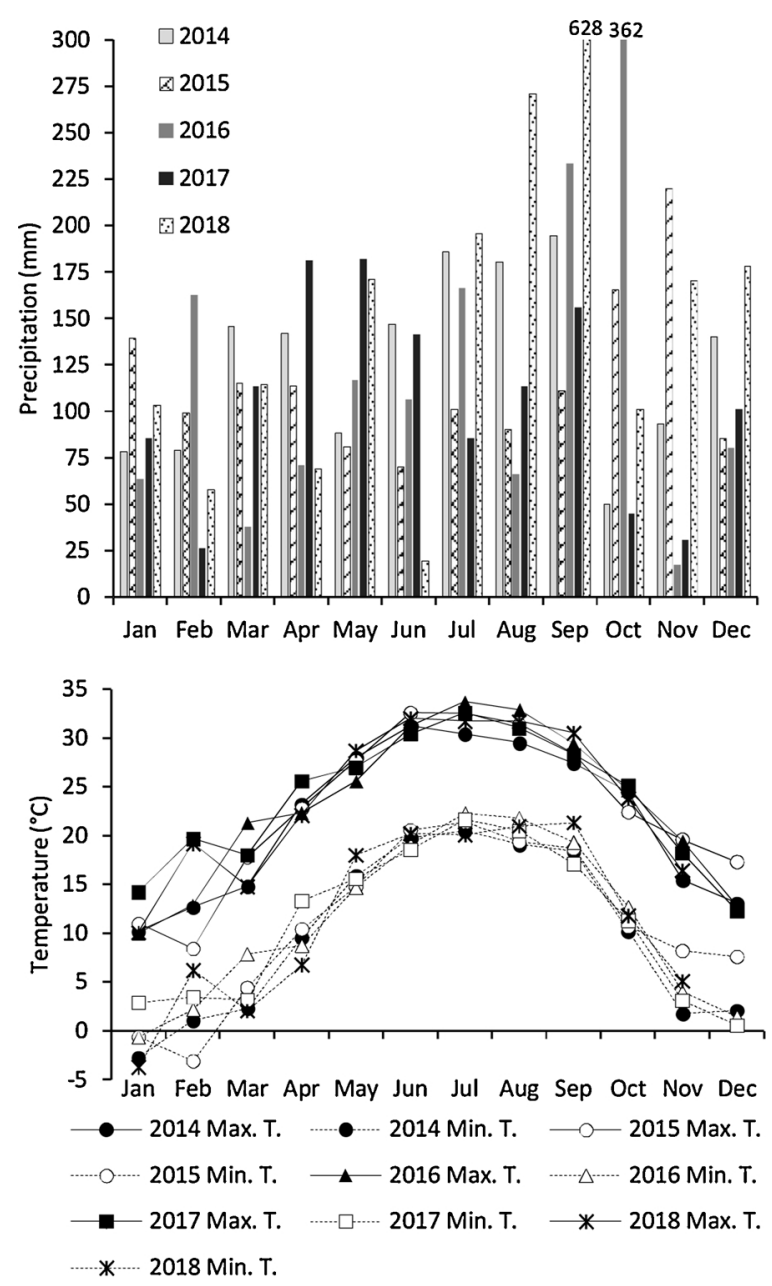

Fig. 2. Observed monthly precipitation and monthly average maximum and minimum temperatures in Goldsboro, NC, USA. Total precipitation (mm) was 1524, 1392, 1484, 1261, and 2081 in years 2014, 2015, 2016, 2017, and 2018, respectively.

area (field-slope $<1 \%$ ) with soil series composition based on the USDA Soil Taxonomy as $48 \%$ Lakeland sand, $43 \%$ Coxville loam, 6\% Chewacla loam, and 3\% Leaf loam. The agroforestry system was originally designed as an alley-cropping system composed of three tree species and two alley widths. The three tree species were: Pinus palustris (PP; longleaf pine), Pinus taeda (PT; lobloblly pine), and Quercus pagoda (QP; cherrybark oak); the two alley-widths were: 12 and $24 \mathrm{~m}$ between lines of trees. Each tree-line consisted of three rows of trees planted in a triangular spacing with distance between trees of 2.1-m in each row, and 2.1-m between tree-rows (Fig. 1).

The overall experimental design displayed areas of apparent maximum shade (i.e. in the middle of each tree-line) and less shade (i.e. in the middle of the alleys) and was setup as a randomized complete block design with five replicates. Within each block, the two alley widths were duplicated, and placement of trees was randomly assigned within blocks, but maintaining the same tree-order in the five lines of trees per block (Fig. 2). The site was managed in a row-crops prior to 2007. Tree seedlings were planted in 2007 and from 2007 to 2012 the alleys between tree-lines were planted every summer to soybeans (Glycine max) or corn (Zea mays). Therefore, the alleys were under annual cropping management for the first 6 years (soybean in 2007, 2009, and 2011; corn in 2008, 2010, and 2012), followed by summer-fallow in 2013 and fall-planted annual ryegrass (Lolium multiflorum) in 2013. Soil properties measured in 2013 from the surface soil $(0-5 \mathrm{~cm})$ were 6.3. for $\mathrm{pH}$, $7.0 \mathrm{cmol}_{\mathrm{c}} \mathrm{kg}^{-1}$ for cation exchange capacity, $82 \%$ base saturation, and
139 and $176 \mathrm{mg} \mathrm{dm}^{-3}$ for $\mathrm{P}$ and $\mathrm{K}$, respectively. In 2014, the site transitioned to perennial-alley cropping with the establishment of native warm-season grasses; hence, hereafter the site will be referred to as a silvopasture system. Lower limbs were pruned from trees every 2-3 years up to a point of $\sim 10 \mathrm{~cm}$ diameter of the main tree-trunk. Limb removal was to encourage single stem vertical growth of trees and to allow equipment access near the tree-lines. The pruned limbs were left on the ground to decompose.

\subsection{Forage establishment and management}

The ryegrass planted in fall 2013 was harvested on 14 April and 23 May 2014. Two weeks after the last harvest, ground cover in alleys was sprayed with herbicide glyphosate (N-[phosphonomethyl] glycine; $1.12 \mathrm{~kg}$ a.i. $\mathrm{ha}^{-1}$ ) in preparation for establishment of the native warmseason perennial grasses. Two seedbed preparation strategies, no-till and conventional-till, were assigned to each of the two alley-widths in each block. This approach was used as an opportunity to evaluate the effect of seedbed preparation on establishment of the perennial native warm-season forage mixture. No-till consisted of drilling the forage seed directly into the herbicide-treated seedbed. Conventional-till consisted of disking several times followed by harrowing to ensure a residue-free and uniform seedbed before planting.

The forage component consisted of a four-way mixture of native warm-season grasses. The grasses were big bluestem (Andropogon gerardii, 'Eastern', KY origin), gamagrass (Tripsacum dactyloides, MO origin), indiangrass (Sorghastrum nutants, 'NC ecotype'), and switchgrass (Panicum virgatum, 'Alamo'). Before planting, the seeds were subjected to a prechilling treatment to break dormancy (Smith et al., 2012). The forage mixture was planted on 7 June 2014 at a total purelive-seed rate (PLS) of $22.4 \mathrm{~kg} \mathrm{ha}^{-1}$ and consisted of $5.6 \mathrm{~kg} \mathrm{ha}^{-1}$ PLS for each type of grass. The planter was a 10-row Truax no-till drill with row-spacing of $15.2 \mathrm{~cm}$ and set to plant to $1.5-\mathrm{cm}$ depth. The planter was equipped with three different seed-boxes to simultaneously plant fluffy seed (i.e., bluestem and indiangrass) and regular small- and largeseeds (i.e., switchgrass and gamagrasss). The planting equipment was maneuvered as close as possible to the edge of each tree-line, but also far enough to prevent damage of trees and tree-roots; therefore, the alleys between tree-lines were planted starting approximately 2.5-m away from the tree-trunks at the edges of the tree-lines. Areas directly under the trees were left unplanted. Total monthly rainfall and maximum and minimum monthly temperatures from 2014 to 2018 were retrieved from a weather station located within a mile from the research site and are presented in Fig. 3. Two major environmental events that resulted in flooded areas at the silvopasture site for several days (from 2 to 7 days), and from which the forages and trees withstood, were hurricane Matthew that brought $362 \mathrm{~mm}$ of rainfall in October 2016 and hurricane Florence with $628 \mathrm{~mm}$ of rainfall in September 2018.

Following sowing of perennial grasses, frequent mowing with a batwing mower set at 20-35 cm height was used to control competition from weeds, prevent weed seed development, and to allow sunlight penetration to encourage establishment of the young grass seedlings. For the purposes of this project, weeds were defined as vegetation different than the planted four-way grass-mixture. Clipping at different heights was the only management practice utilized to manage competition from weeds and to encourage forage establishment; no herbicides were used. In 2014, the forage was initially clipped to $20 \mathrm{~cm}$ height when the average canopy was approximately $30-40 \mathrm{~cm}$; later in that growing season and throughout 2015 and 2016, clipping height was adjusted based on the height and maturity of the grasses to allow full expansion of the planted grass-species. No fertilizer was applied during 2014-2016 period. The areas utilized for this experiment were located in the 24-m wide alleys from Blocks 2, 3, and 4 (Fig. 2). The selected areas were clipped two times per year, once at mid-season (target of 15 June) and at the end of the growing season (target of 1 September). 


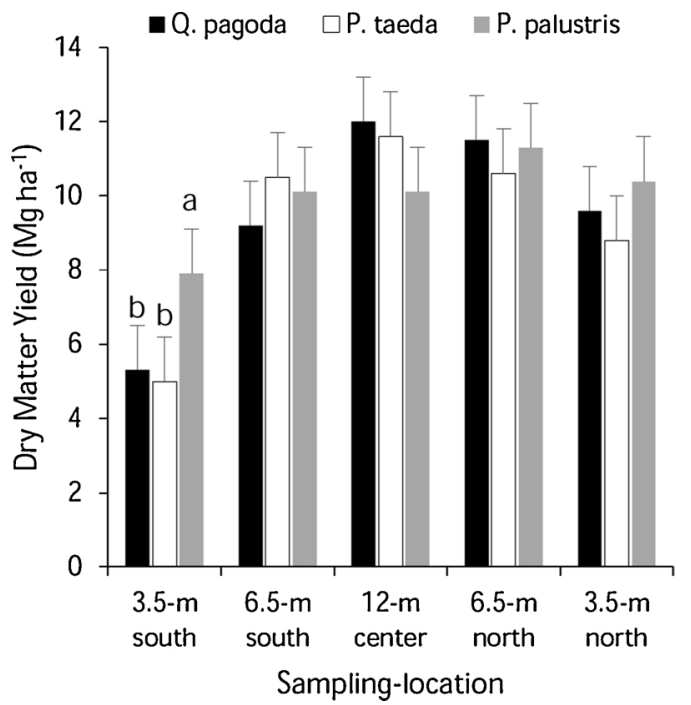

Fig. 3. Dry matter yield of the native-grass forage mixture by sampling-location. Data are means of two years and three replicates $(n=6)$. Error bars represent 1 SE of estimated effects over the whole experiment. Bars within sampling location followed by different lowercase letters are different $(P \leq$ 0.05).

Clipping twice a year for native warm-season grasses was selected as the management practice because it may allow farmers the flexibility of using the first clipping as higher nutritive value forage and the second clipping as bioenergy feedstock (Richner et al., 2014; Waramit et al., 2011). In 2017, liquid urea-ammonium-nitrate was applied on 7 July 2017 at a rate of $67 \mathrm{~kg} \mathrm{~N} \mathrm{ha}^{-1}$. In 2018, poultry litter was applied on 3 May at a rate of $4.5 \mathrm{Mg} \mathrm{ha}^{-1}$ and followed by application of liquid ureaammonium-nitrate on 22 June at a rate of $67 \mathrm{~kg} \mathrm{~N}^{-1}$.

\subsection{Response variables}

\subsubsection{Forage establishment evaluation}

Dry matter yield and botanical composition were evaluated on 23 September 2015 with the objective of monitoring establishment and to compare the impact of seedbed preparation (tilled vs. no-till) on forage establishment. Measurements were taken in the 24-m wide alleys. Dry matter yield was estimated by clipping to $15-\mathrm{cm}$ stubble height within a $3.2-\mathrm{m}^{2}$ frame. Forage was clipped from three randomly chosen locations within the alleys. The clipped forage was weighed fresh in the field, three subsamples (500-1000 g) were taken for determination of dry matter (DM) concentration, DM yield, and to determine botanical composition by weight. The average of the three samples provided an estimate of DM yield per experimental unit. Botanical composition by weight was estimated by separating each of the three fresh sub-samples in five components. The five components were: big bluestem, gamagrass, indiangrass, switchgrass, and weeds. The separated components were dried and botanical composition by weight was estimated as the proportion of each component's weight relative to the total dry weight of the sub-sample, and averaged for the three sub-samples to provide an estimate per experimental unit.

\subsubsection{Forage dry matter yield and nutritive value}

Sampling occurred on 13 June and 13 September in 2017 and 7 June and 9 October in 2018. Total annual DM yield was calculated by adding the two clippings per year. Forage was sampled at five locations along the 24-m wide transect between tree-lines. At each sampling-location the forage was clipped to $15-\mathrm{cm}$ stubble-height using a $3-\mathrm{m}^{2}$ sampling frame (1-m wide by $3-\mathrm{m}$ long). The width of the frame was placed following the direction of the transect and the center of frame was placed at 3.5 and $6.5 \mathrm{~m}$ away from each tree-line (north and south) and at the center of the alley $(12 \mathrm{~m})$; hereafter the five sampling-locations will be referred to as: 3.5-m south, 6.5-m south, 12 (center), 6.5-m north, and $3.5-\mathrm{m}$ north. The starting point closest to the tree-lines was 3-m away from the inner-most tree-row because the grasses were intentionally planted in that way in the original design; consequently, the grass-planted strip was actually $18-\mathrm{m}$ wide, which corresponds to $65 \%$ of the total width $(27.6 \mathrm{~m})$ of each experimental unit including the areas under the tress not planted with forages. The clipped herbage was weighed fresh in the field and a sub-sample $(\sim 1000 \mathrm{~g})$ was dried at $60{ }^{\circ} \mathrm{C}$ until constant weight to determine DM concentration, DM yield, and nutritive value. Total forage DM yield per tree-species system was calculated by linearly interpolating DM yield between the five sampling-locations and integrating DM yield along the 27.6-m width of each experimental unit.

Nutritive value was characterized by total digestible nutrients (TDN) and crude protein (CP). Concentrations of TDN and CP were determined using near-infrared (NIR) spectroscopy by correlating NIR spectra to wet-chemistry values. Samples were scanned using a 5000 NIRS equipment (Foss North America, Inc., Eden Prairie, MN) and reflectance was determined in $2 \mathrm{~nm}$ wavelength-increments (from 1100 to $2500 \mathrm{~nm}$ ). Wet chemistry analyses were performed by the Dairy One Laboratory (Ithaca, NY) (Dairy One, 2015). We selected 72 samples, out of a total of 180 samples for the experiment, for wet chemistry analysis, model calibration, cross-validation, and prediction by adapting a data analysis pipeline created under the $\mathrm{R}$ environment that was originally developed for study of wood chemistry (Hodge et al., 2018; R Core Team, 2016). The selected samples were chosen using a stratified random sampling approach to ensure that at least one sample from each harvest and sampling-location combination was included and to represent the range of the sample population. Information of fit statistics for the selected models is presented in Table 1. Desirable NIR models are those that maximize the coefficient of determination $\left(\mathrm{R}_{\mathrm{CV}}^{2}\right)$, minimize the standard error of cross-validation (SECV), and have a small number of latent variables (Hodge et al., 2018). These equations were then used to predict the nutritive value of the remaining samples.

\subsubsection{Tree-height (TH), diameter at breast height (DBH), and light environment}

Tree-height and DBH were measured on 16 November 2017 with the objective of characterizing the tree component of the system. A total of 20 trees per experimental unit were selected randomly by choosing 10 trees from each tree-line (north and south). Within each tree-line, 5 trees corresponded to the edge tree-row and the other 5 corresponded to the center tree-row. The average of the 20 trees provided an estimate of $\mathrm{TH}$ and $\mathrm{DBH}$ per experimental unit. The DBH was determined by wrapping a measuring tape around the tree-trunk at $1.37-\mathrm{m}$ height from the ground-level and TH was determined by using a clinometer.

Understory light environment was quantified at the middle of each tree-line (north and south) and in the middle of the alleys; hereafter referred to as 0-m north, 0-m south, and 12-m center, respectively. Light environment at the top of the grass canopy $(\sim 1.5 \mathrm{~m}$ from the soil surface) was characterized using a SunScan Canopy Analysis System (Dynamax) to measure transmitted photosynthetically active radiation

Table 1

Fit statistics of calibration models for total digestible nutrients (TDN) and crude protein $(\mathrm{CP})$.

\begin{tabular}{llllll}
\hline Constituent & $\begin{array}{l}\text { Mathematical pretreatment (\# } \\
\text { of factors) }\end{array}$ & $\mathrm{R}_{\mathrm{C}}^{2}$ & $\mathrm{R}_{\mathrm{CV}}^{2}$ & $\mathrm{SEC}$ & SECV \\
\hline & & & & \multicolumn{2}{c}{$\mathrm{g} \mathrm{kg}^{-1}$} \\
TDN & DT_SG-7 (8) & 0.98 & 0.91 & 0.4 & 0.7 \\
CP & SG-7 (7) & 0.98 & 0.93 & 0.2 & 0.4 \\
\hline
\end{tabular}

${ }^{\text {a }}$ DT = Detrend; SG-7 = Savitzky-Golay smoothed spectra using seven points. 
(PAR) and incident PAR. The system consisted of two sensors, a 1-m long quantum sensor to measure transmitted PAR that was placed in five locations under the tree-lines and in the middle of the alley, and an unshaded beam fraction sensor that was placed outside the plots at the open-pasture to measure incident PAR. The sensors were wirelessly synchronized to take PAR readings simultaneously. Light measurements were taken between 1200 and $1400 \mathrm{~h}$ during the summer (on 13 June 2017 and 29 June 2018) and winter (on 24 January 2018 and 31 January 2019). Light environment was calculated by dividing the transmitted PAR by the incident PAR and multiplied by 100 to express it as a percentage (Castillo et al., 2013); consequently, in a scale of $0-100 \%$, a value of $100 \%$ is an environment with no influence of treeshade while lower values are indicative of the effect of tree-shade. The average of the five measurements provided an estimate for light environment for each experimental unit.

\subsubsection{Air temperature (TEMP), relative humidity ( $R H)$, and temperature-} humidity index (THI)

Dry bulb temperature $\left({ }^{\circ} \mathrm{C}, \mathrm{T}_{\mathrm{db}}\right)$ and relative humidity were recorded from April to September 2017 and from February to August in 2018. A total of twelve $\mathrm{HOBO}^{\circledR}$ sensors/loggers (model U23 Pro V2; Onset Company, Bourne, MA) were placed under the trees and in an adjacent open pasture (Fig. 2) at a height of $\sim 1.5 \mathrm{~m}$ from the ground-level and were deployed to take records at 15-min intervals. Under the trees, the sensors were located in the middle of the three tree-rows per tree-line. The vegetation in the open pasture consisted of the same four-way mixture of native warm-season grasses and it was originally established one year later in 2015. The temperature-humidity index (THI) was calculated as: $\mathrm{THI}=\left(1.8 \times \mathrm{T}_{\mathrm{db}}+32\right)-[(0.55-0.0055 \mathrm{x} \mathrm{RH}) \times(1.8 \mathrm{x}$ $\mathrm{T}_{\mathrm{db}}$ - 26.8)] (National Research Council (NRC), 1971; Dikmen and Hansen, 2009; Igono et al., 1992; West, 2003; Misztal, 2017).

\subsection{Experimental design and statistical analysis}

The overall field experimental design was a randomized complete block design. Treatment effects were considered significant if $P \leq 0.05$. For forage establishment evaluation, treatments were the two seedbed preparations, till vs. no-till. For botanical composition, the treatment design was the factorial combination $(2 \times 5)$ of seedbed preparation (till vs. no-till) and component (big bluestem, indiangrass, gamagrass, switchgrass, and weeds). Analysis of variance was performed with treatments modeled as fixed effects and blocks as random effects. Data for botanical composition was squared-root transformed to comply with normality assumption during analysis and then back-transformed to its original scale for presentation of results.

For DM yield and nutritive value, treatment design was the factorial combination $(3 \times 5)$ of the three tree species $(\mathrm{PP}, \mathrm{PT}$, and QP) and five sampling locations [3.5-m north, 6.5-m north, 12-m center, and 3.5-m south, and 6.5-m south]. Data were collected for two years (2017 and 2018). Analyses of variance were set up to compare the impact of tree species on forage DM yield and nutritive value at each sampling location and to compare the total systems DM yield. Statistical models for analyses included treatments as fixed effects and block and year as random effects. Analysis by sampling-location was set up using the SLICE function and treatment means were separated using the LINES functions in SAS.

For TH and DBH, treatments were the three tree-species (PP, PT, and QP) and data were analyzed as a randomized complete block design replicated 3 times. For light environment, data were analyzed by location, and treatments were the factorial combination of three treespecies (PP, PT, and QP) and season of the year when measurements were taken (winter and summer).

For TEMP, RH and THI, the analysis was split into two steps. In the first step, 6 -hs overlapping windows were created, records from this timeframe were extracted $(n=288,6$ h by 4 hourly recordings over 12 sensors and analyzed with a model that included the fixed effects of

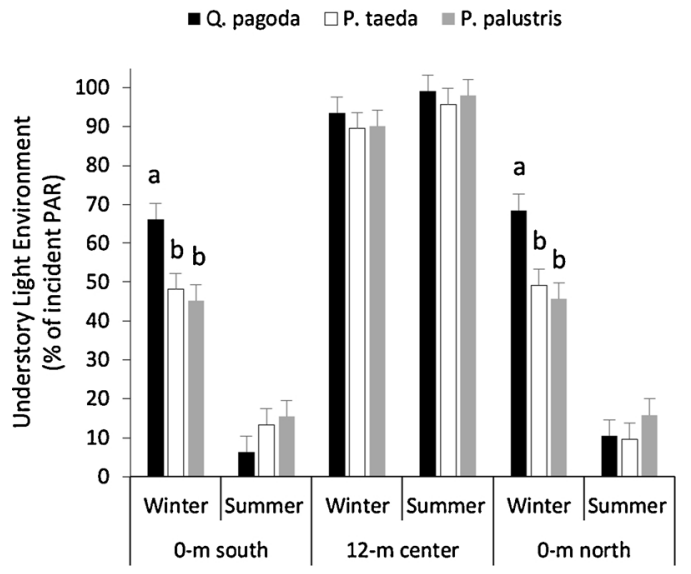

Fig. 4. Understory light environment (\% of incident photosynthetic active radiation, PAR) as a function tree, sampling-location, and season of the year. Error bars represent 1 SE of estimated effects over the whole experiment. Bars within sampling location followed by different lowercase letters are different ( $P$ $\leq 0.05)$.

hour of the day 6 levels, location [open pasture OP vs 3-tree species] and random effect of sensor 12 levels, nested within location. From this model, coefficient estimates for the 3-tree species were extracted and they are to be interpreted as mitigation parameters MIT that each tree species is capable of providing as compared to the open-pasture, in a given time of a given day across the data recording period. The analysis was repeated independently for TEMP, RH and THI; a total of 9698 windows were analyzed. Statistical analyses were conducted using the package 'MCMCglmm' package implemented in R Hadfield, 2010. Convergence was assessed using Geweke statistics on the chains after burn-in samples were removed and only runs showing Geweke's value lower than 1 for all parameters were retained. After this step, only 8184 windows were included into the next step. In the second step of the analysis, the MIT parameters were used as the dependent variable, and analyzed to identify in what conditions each species of tree was capable of providing the stronger mitigation. The MIT parameters from each window were matched to the respective tree species and day of collection. The time of the day of the window first hour of recording for each window was simplified into two categories. Sunrise and sunset time for the location of the experiment was downloaded from the internet www.sunrise-sunset.org) for each day of duration of the experiment. Windows were classified as DAY if at least $50 \%$ of the time covered was included in the sunrise-to-sunset interval for that day, otherwise were classified as NIGHT.

The parameters TEMP, RH and THI were analyzed independently. The model included the fixed effects of tree-species (3 levels), time of the day (DAY vs NIGHT), year-month of recording (YM, 10 levels), and first-order and second-order interactions between the MIT parameters for TEMP, RH, and THI effects. Random effect of recording block was included, defined as the concatenation of tree-species, time of the day and year-month-day of recording. For this step, the MIXED procedure was used (SAS, 2008). Least-squares means for the tree- species by time of the day by year-month were calculated and plotted in part B of Figs. 6 and 7 for TEMP, RH, and THI, respectively. An additional analysis, similar to the second step, was performed to analyze the TEMP, $\mathrm{RH}$ and THI variables as recorded in the OP. This analysis was performed using the MIXED procedure with a model that included effects of time of the day, year-month of recording and their interaction. Leastsquares means for the interaction term were calculated and plotted in part A of Figs. 6, 7 and 8. 

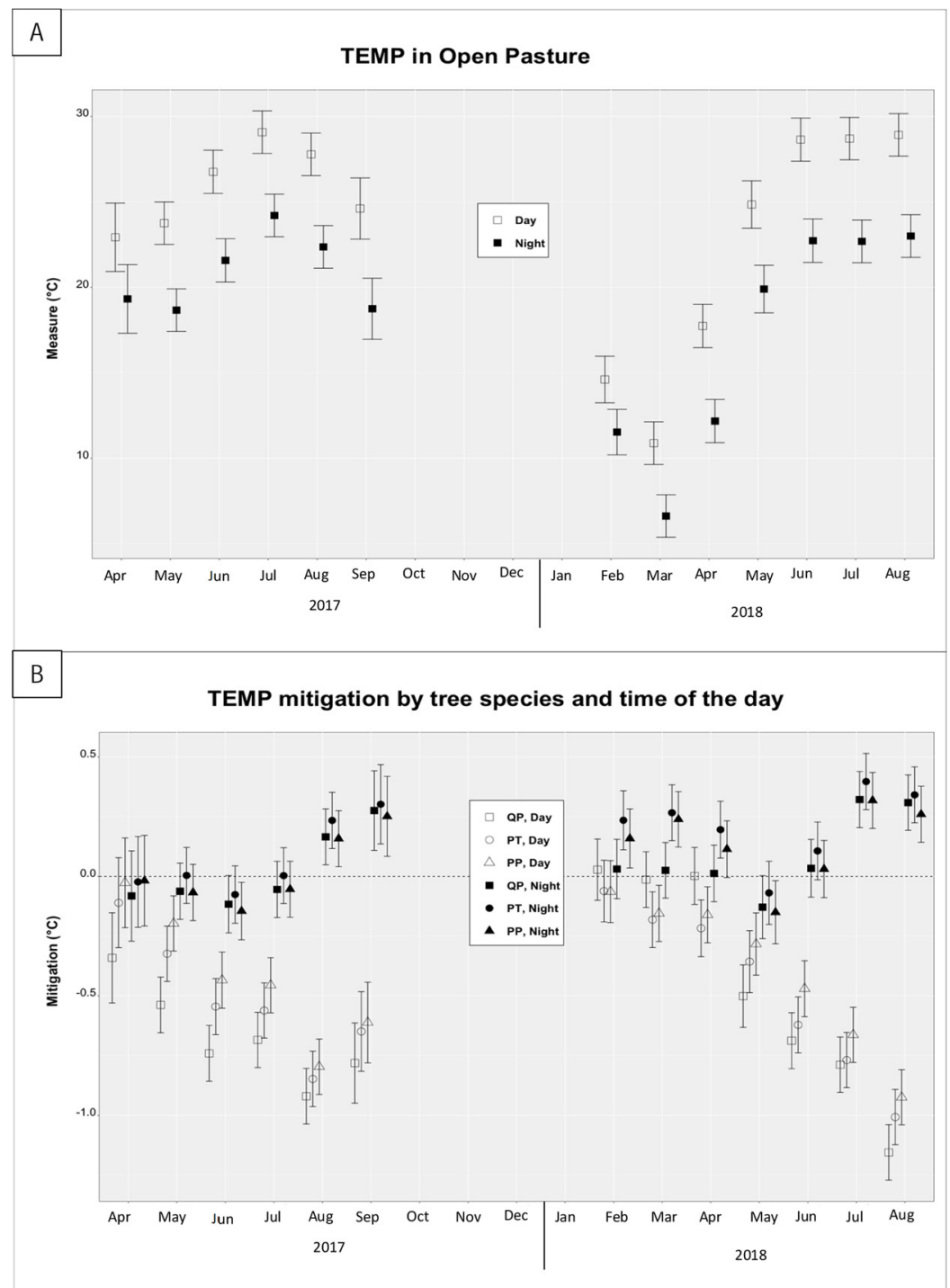

Fig. 5. Temperature (TEMP) in (A) open pasture and (B) mitigation by tree-species (QP $=$ Quercus pagoda, $\mathrm{PT}=$ Pinus palustris, $\mathrm{PT}=$ Pinus taeda) as a function of time of day and month of the year in a silvopasture in North Carolina, USA. The error bars report $95 \%$ confidence intervals.

\section{Results and discussion}

\subsection{Establishment evaluation}

Seedbed preparation had no effect on DM yield. The DM yield was $\sim 4.1 \mathrm{Mg} \mathrm{ha}^{-1}$ (SE $=0.38 ; \mathrm{P}=0.33$ ). There were differences in botanical composition $(\mathrm{P}<0.001)$. Switchgrass was the dominant species (57 \%), followed by weeds ( $28 \%$ ), followed by indiangrass (6\%), and followed by bluestem and gamagrass $(\leq 3 \%)$. The plant species in the weeds category were mainly warm-season annuals such as large crabgrass [Digitaria sanguinalis (L). Scop.] and to a lesser extent broadleaf signalgrass [Brachiaria plattyphylla (Griseb.) Nash], and horseweed [Conyza canadensis (L.) Cronq.], in addition to the perennial dogfennel (Eupatorium capillifolium).

Establishment of the planted forage mixture was evaluated at the end of the second growing season in our experiment. Literature suggest that native-grass swards improve and dominate the stand until about the third growing season, when they become fully established (Keyser et al., 2015). In the context of grazing or clipping, limited competition from warm-season annual weed-species is expected because of the higher residual stubble height recommended for management of native warm-season grasses (Busey, 2003; Bekewe et al., 2019a). In addition, crabgrass is a nutritious warm-season annual grass and readily grazed by cattle compared with most other warm-season grasses (Beck et al., 2007). Successful establishment of the native-grass mixture and limited weed infestation in the planted-alleys were later confirmed when samples were collected to determine DM yield and nutritive value in 2017 and 2018.

\subsection{Tree-height, diameter at breast height, and light environment}

Tree height and DBH were different among tree species $(\mathrm{P}<0.001$ for both TH and DBH; $\mathrm{SE}=1.4$ for TH; $\mathrm{SE}=0.7$ for $\mathrm{DBH}$ ). The TH was greatest for PT $(29.8 \mathrm{~m})$, intermediate for PP $(19.7 \mathrm{~m})$, and lowest for QP (15.2 m). The DBH estimates followed the same pattern as TH; DBH estimates were 20.0, 15.2, and $10.4 \mathrm{~cm}$ for PT, PP, QP, respectively.

The average maximum daily solar radiation per month measured at solar noon ranged from 492 to $1152 \mathrm{~W} \mathrm{~m}^{-2}$, with the lower values occurring in winter (between November and February). Understory light environment (measured as relative PAR around noon) ranged from 6.3-99\% (Fig. 5). At the center of the alleys, light environment was $\geq$ $90 \%$ for all tree-species across sampling seasons (winter and summer). In contrast, at sampling locations $0-\mathrm{m}$ north and $0-\mathrm{m}$ south the understory light environment during summer was $\leq 15 \%$ for all tree- 

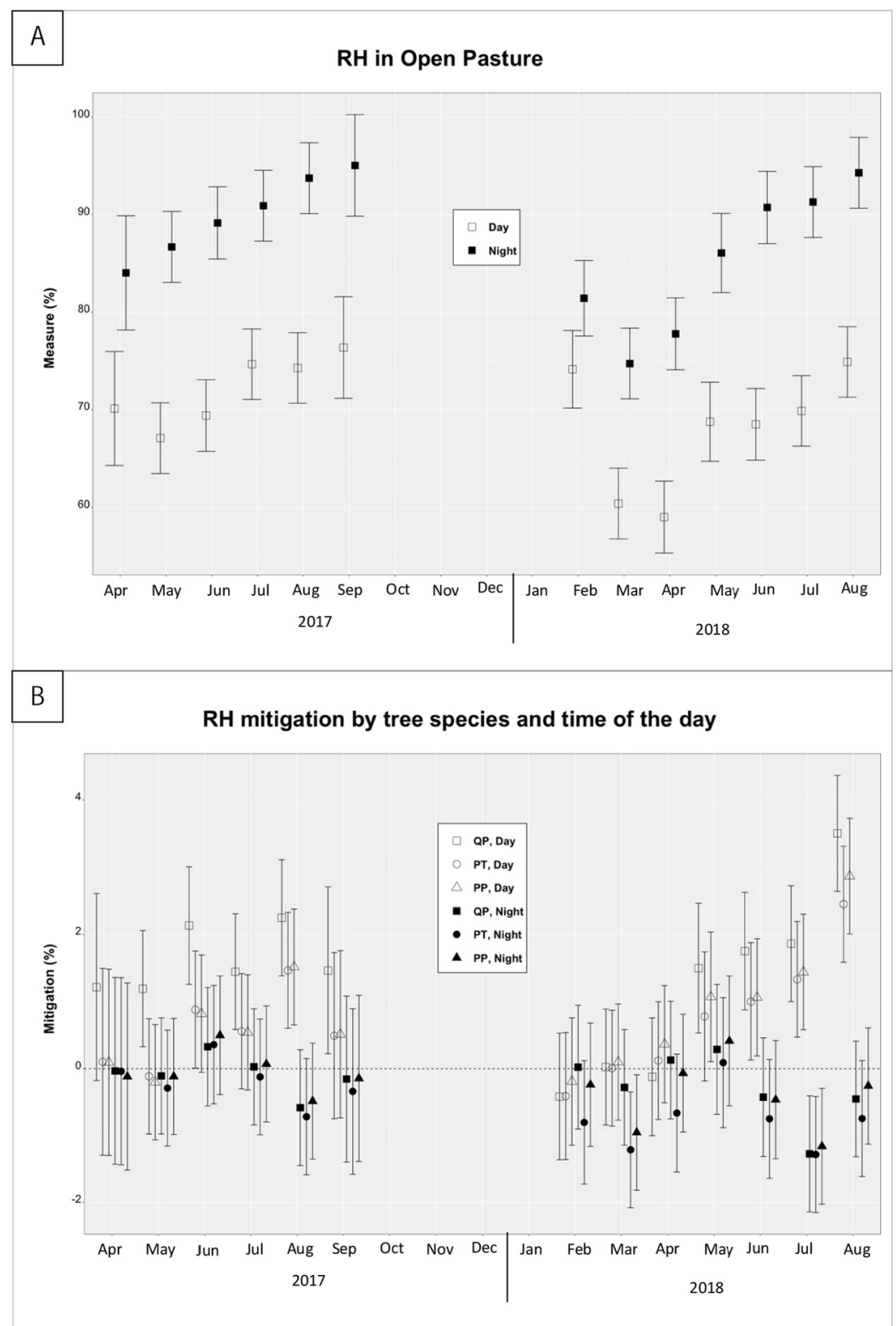

Fig. 6. Relative humidity (RH) in (A) open pasture and (B) mitigation by tree-species (QP = Quercus pagoda, $\mathrm{PT}=$ Pinus palustris, $\mathrm{PT}=$ Pinus taeda) as a function of time of day and month of the year in a silvopasture in North Carolina, USA. The error bars report $95 \%$ confidence intervals.

species; however, during winter the understory light environment was greater for QP (approximately $67 \%$ of incident PAR) compared to PP and PT (approximately $47 \%$ of incident PAR for both tree-species). In our experiment, light environment was greatest at the center of the alley, and it was lower and it varied as a function of season of the year at the $0-\mathrm{m}$ north and $0-\mathrm{m}$ south locations. These results highlight the potential of our specific silvopastoral system design to provide yearround areas of high and low light (or shade) environment to protect livestock from direct and indirect solar radiation.

\subsection{Forage DM yield and nutritive value}

There was a tree-species by sampling location interaction for DM yield $(P=0.05)$. The interaction effect occurred because DM yield differences due to tree species were present only at the $3.5-\mathrm{m}$ south sampling-location but not in the other locations (Fig. 4). Averaged across tree species, DM yield was lower at the $3.5-\mathrm{m}$ south location (6.1 $\mathrm{Mg} \mathrm{ha}^{-1} \mathrm{yr}^{-1}$ ) compared to the other sampling-locations (ranged from $9.6-11.2 \mathrm{Mg} \mathrm{ha}^{-1} \mathrm{yr}^{-1}$ ). It is not completely clear why DM yield at the 3.5-m south sampling-location was lower; however, we hypothesized that lower DM yield at the south sampling-location was a function of the combined effect of human-disturbance that occurred when setting up a fence-line and resource competition with the trees. The apparent "umbrella-shape" pattern of lower yields closer to tree-lines compared to the middle of the alleys in our experiment is consistent with previous reports in perennial alley-cropping systems (Gamble et al., 2016). Under greenhouse conditions and working with switchgrass 'Alamo', Albaugh et al. (2014) reported significant reductions in above- and below-ground biomass when shade increased from 0 to 76 $\%$. In our experiment, the native grass mixture was originally planted starting approximately 3-m away from the tree-trunk and, with the exception of the 3.5-m south sampling-location, we did not detect differences in DM yield due to tree species at the other sampling locations. As trees and their canopies develop over time, it is possible that treeshade could potentially impact forage growth and that tree species effect become more apparent starting in areas closer to the trees. Total DM yield of the whole plot was not different among tree-systems and $\mathrm{DM}$ yield averaged 6.6 $\mathrm{Mg} \mathrm{ha}^{-1} \mathrm{yr}^{-1}$. 


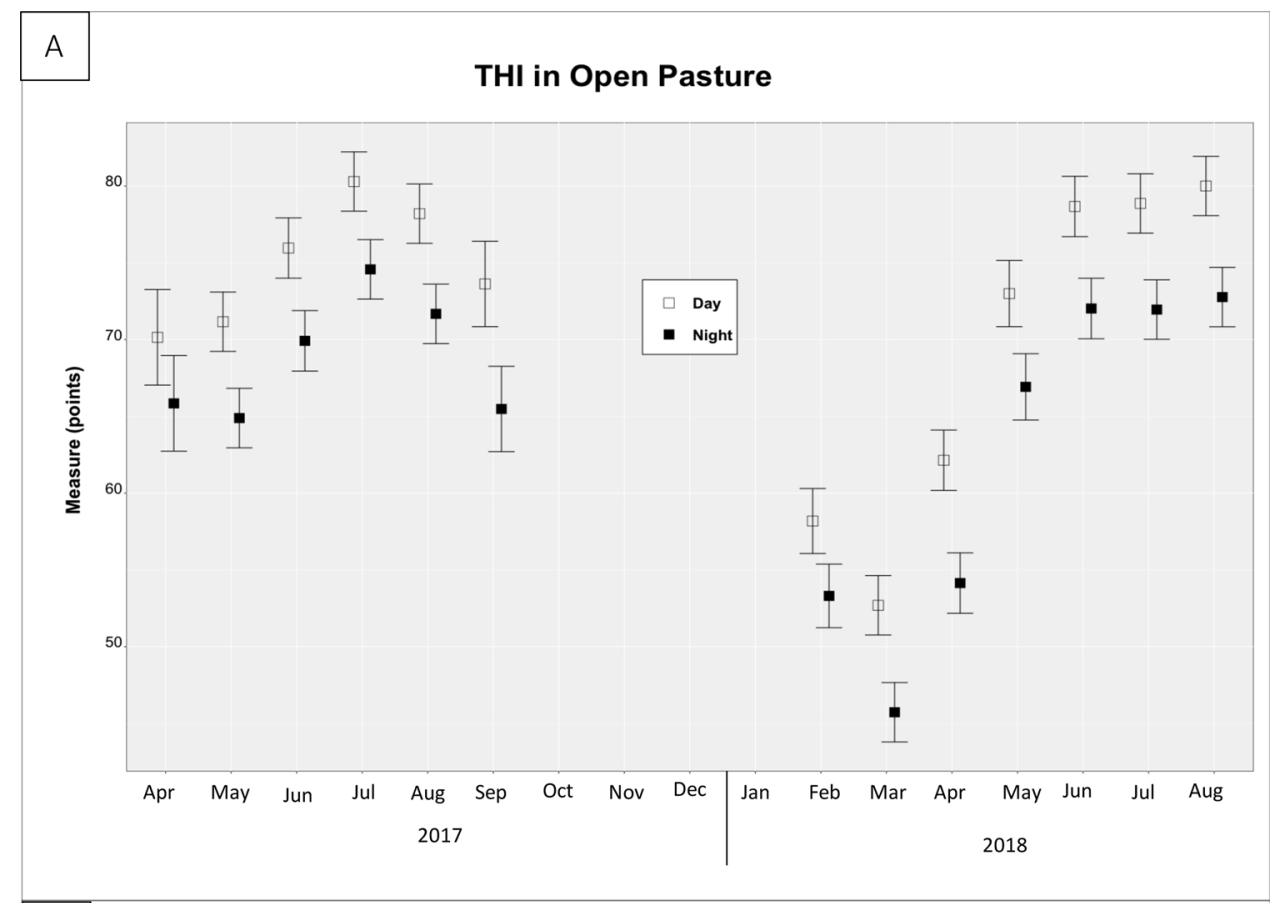

B

THI mitigation by tree species and time of the day

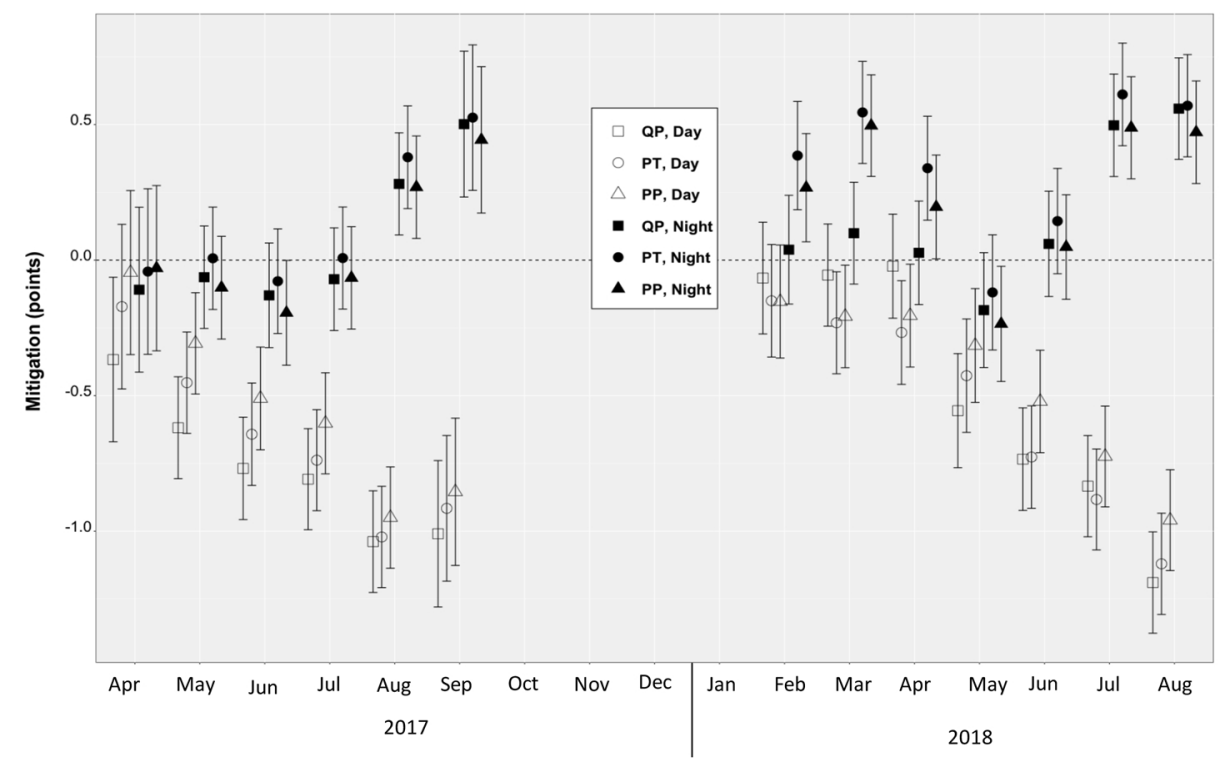

Fig. 7. Temperature-humidity index (THI) in (A) open pasture and (B) mitigation by tree-species (QP = Quercus pagoda, $\mathrm{PT}=$ Pinus palustris, $\mathrm{PT}=$ Pinus taeda) as a function of time of day and month of the year in a silvopasture in North Carolina, USA. The error bars report $95 \%$ confidence intervals.

Nutritive value estimates of TDN and $\mathrm{CP}$ of the native-grass mixture were similar in the three tree-species systems. Concentrations of TDN and CP ranged from 543 to 593 and from 50 to $77 \mathrm{~g} \mathrm{~kg}^{-1}$, respectively. Crude protein values were greater for the end-of-season clipping in both years and this effect is attributed to the timing and source of $\mathrm{N}$ fertilization. In both years, inorganic fertilizer was applied mid-summer after the first clipping event. In 2017, no spring fertilizer was applied and in 2018, poultry litter was applied. Both nutritive value estimates, TDN and $\mathrm{CP}$, are considered insufficient to meet livestock requirements if the harvested forage is the only source of feed. According to the National Research Council (NRC) (1996), the CP concentration needed to meet the requirements of a non-pregnant non-lactating mature cow is $89 \mathrm{~g}$ $\mathrm{kg}^{-1}$. Lower nutritive value estimates in the harvested forage were due to mature forage that was harvested at the reproductive stage. Switchgrass was the dominant grass species in the mixture and there are numerous reports of greater nutritive value estimates for switchgrass when it is harvested at younger maturity (vegetative stage) compared to reproductive stage (Bekewe et al., 2009b; Burns et al., 1997). Therefore, under the current management, the harvested forage may have potential as bioenergy feedstock or other uses different than feed for livestock. Lower TDN and CP values, concomitant with greater fiber concentration values, have been previously reported in the literature numerous times for warm-season grasses when the forage is harvested at greater maturity stages (Griffin and Jung, 1983; Perry and Baltensperger, 1979; Richner et al., 2014). This includes specific reports for switchgrass in NC (Bekewe et al., 2019b; Burns et al., 1997), which 
was the dominant grass species in our experiment

\subsection{Air temperature, relative humidity, and temperature-humidity index}

Estimates of TEMP, RH, and THI by time-of-day and year-month in the open-pasture are presented in section A of Figs. Fig. 66 and Fig. 77, respectively. In the open-pasture, TEMP and THI were greater during the day while RH was greater during the night. In general, greater estimates of TEMP, RH, and THI for both DAY and NIGHT occurred during spring and summer months vs. fall and winter. The mitigation potential of trees to alter TEMP, RH, and THI are reported in section B of Figs. Fig. 66 and Fig. 77, respectively. The MIT estimates are reported as the difference between the open pasture and under a specific tree in the corresponding time of day and year-month. The dashed horizonal line at "zero" in section B of each figure depicts the corresponding values reported in section $A$ for each time of day and year-month.

Temperature mitigation was not different due to species of trees and it was strongly dependent on month-of-the-year and time-of-day (Fig. 6B). Significant differences were predominantly present during the summer-months. Greatest TEMP mitigation values were $-1^{\circ}$ for DAY and $+0.5^{\circ}$ for NIGHT. No significant mitigation occurred during winter and spring year-months. Differences were seldom significant among tree-species, although there was a tendency to show a stronger mitigation provided by QP. The pattern of lower temperatures during the day and higher temperatures during the night between agroforestry plots was also reported by Gosme et al. (2016). The authors worked with poplar (Populus $x$ canadensis) and ash (Fraxinus excelsior L.) trees in the south of France and reported temperature differences only on clear days (as opposed to cloudy days). Relative humidity mitigation was not different due to tree species and differences were significant and most noticeable during the summer months. Greatest mitigation was +3 points for DAY and -1 point for NIGHT. A similar pattern for RH was reported by Corlett et al. (1989). For THI mitigation, there were no differences among tree-species and mitigation values were greater during the summer months. Greatest mitigation values were +0.5 points during NIGHT and -1 point for DAY.

Although TEMP, RH, and THI had relatively moderate mitigation effects, the presence of shade offered to livestock should still be considered significant in grazing systems in the southeastern USA. Absorption of heat from incoming solar radiation by livestock should be considered in addition to ambient air temperature. Other measures of heat stress are needed to fully characterize this phenomenon, with the ultimate effects on animal responses measured for a specific type and breed of livestock.

The effects of heat stress on livestock, and the benefits of providing shade, manifest themselves in multiple physiological, metabolic, reproductive, and behavioral responses, as reviewed by Blackshaw and Blackshaw (1994) and West (2003). Cows provided with shade have significantly lower respiration rates and core body temperature than cattle without shade in warm summer conditions (Sethi and Nagarcenkar, 1981; Blackshaw and Blackshaw, 1994). Utilization of shade by cattle increases as average solar radiation increases (Tucker et al., 2008) and it could reduce total heat load by $30-50 \%$ (Bond and Kelly, 1955; Bond et al., 1967). In a West Texas feedlot with artificial shade, Angus-crossbred and Charolais-crossbred heifers reached their target body weight 3 wk earlier compared to unshaded cattle (Mitlöhner et al., 2020).

\section{Conclusions and implications}

Understory forage dry matter yield and nutritive value were not affected by tree species at different distances from the tree lines. There was one exception were yield differences in one sampling location only were attributed to human-induced disturbance. However, as trees continue to grow, it may be possible that forage productivity, and especially dry matter yield for this particular selection of forages, could become negatively affected starting in areas near to the tree lines. The mitigation potential of trees on temperature, relative humidity, and temperature-humidity index was moderate and it varied as a function of time of the day and month of the year and it was more noticeable during the daytime of summer months. The mitigation potential was at the most $1^{\circ}$ for temperature and temperature-humidity index and 3 points for relative humidity. It remains unknown, however, whether the aforementioned shifts in microclimate will be of significance to affect responses of a specific type of livestock or if the mitigation potential would be enough to counterbalance the possible effects of climate change. The main feature of the silvopastoral system's design in our study is the provision of year-round shade by the tree-component, with varying levels of shade due to tree species and season. The silvopasture system in this study showed potential to significantly mitigate exposure to radiant heat, while allowing direct sunlight penetration for forage growth between the tree-lines. Our results describe and highlight the potential of an intercropping silvopastoral system design in the southeastern USA, its effects on forage productivity, and its microclimate.

\section{Declaration of Competing Interest}

The authors declare that they have no known competing financial interests or personal relationships that could have appeared to influence the work reported in this paper.

\section{Acknowledgements}

The authors express their appreciation to the personnel at the Cherry Research Farm Station in Goldsboro, NC, for managing the site; to the faculty and staff of the Center for Environmental Farming Systems (CEFS) for their vision in establishing this experiment; and to several students and visiting scholars that participated in field activities. Thanks to the group of faculty and students from Universidad Nacional Toribio Rodríguez de Mendoza and Universidad Nacional Agraria La Molina, Perú, and to Stephanie Sosinski, Erin Silva, and Ellen Leonard, for their excellent technical support with field and laboratory activities.

\section{References}

Albaugh, J.M., Albaugh, T.J., Heiderman, R.R., Legget, Z., Stape, J.L., King, K., O’Neill, K.P., King, J.S., 2014. Evaluating changes in switchgrass physiology, biomass, and light-use efficiency under artificial shade to estimate yields if intercropped with Pinus taeda L. Agroforestry Syst 88, 486-503.

Armstrong, D.V., 1994. Heat stress interaction with shade and cooling. J. Dairy Sci. 77, 2044-2050.

Beck, P.A., Hutchinson, S., Stewart, C.B., Schockey, J.D., Gunter, S.A., 2007. Effect of crabgrass (Digitaria ciliaris) hay harvest interval on forage quality and performance of growing calves fed mixed diets. J. Anim. Sci. 85, 527-535. https://doi.org/10.2527/ jas.2006-358.

Bekewe, P.E., Castillo, M.S., Rivera, R., 2019a. Harvest management effects on canopy height and light interception of 'Performer' switchgrass and its relationship with weed infestation. Crop Sci. 59, 1309-1316.

Bekewe, P.E., Castillo, M.S., Acosta, J.J., Rivera, R., 2019b. Defoliation management effects on nutritive value of 'Performer' switchgrass. Crop Sci. https://doi.org/10. 1002/csc2.20036. (in press).

Bennet, E.M., Peterson, G.D., Gordon, L.J., 2009. Understanding relationships among multiple ecosystem services. Ecol. Lett. 12, 1-11.

Blackshaw, J.K., Blackshaw, A.W., 1994. Heat stress in cattle and the effect of shade on production and behaviour: a review. Aust. J. Exp. Agric. 34, 285-295.

Bond, T.E., Kelly, C.F., 1955. The globe thermometer in agriculture research. Agric. Eng. $36,251-255$.

Bond, T.E., Kelly, C.F., Morrison, S.R., Pereira, N., 1967. Solar, atmospheric and terrestrial radiation received by shaded and unshaded animals. Trans. Am. Soc. Agric. Eng. $10,622-627$

Burns, J.C., Pond, K.R., Fisher, D.S., Luginbuhl, J.M., 1997. Changes in forage quality, ingestive mastication, and digesta kinetics resulting from switchgrass maturity. J. Anim. Sci. 75, 1368-1379.

Busey, P., 2003. Cultural management of weeds in turfgrass, a review. Crop Sci. 43, 1899-1911.

Castillo, M.S., Sollenberger, L.E., Blount, A., Ferrell, J.A., Na, C., Williams, M., Mackowiak, C., 2013. Seedbed preparation techniques and weed control strategies for strip-planting rhizome peanut into warm-season grass pasture. Crop Sci. 54, 
1868-1875.

Corlett, J.E., Ong, C.K., Black, C.R., 1989. Microclimatic modifications in intercropping and alley-cropping systems. In: International workshop on the Applications of Meteorology to Agroforestry Systems Planning and Management. Nairobi (Kenya), 9-13 Feb. 1987. Icraf.

Cubbage, F., Glenn, V., Mueller, J.P., Robinson, D., Myers, R., Luginbuhl, J.M., Myers, R., 2012. Early tree growth, crop yields, and estimated returns for an agroforestry trial in Goldsboro, North Carolina. Agroforest. Syst. 86, 323-334.

Dagang, A.B.K., Nair, P.K.R., 2003. Silvopastoral research and adoption in Central America, recent findings and recommendations for future directions. Agroforestry Syst. 59, 149-155.

Deiss, L., Franzluebbers, A.J., de Moraes, A., 2017. Soil texture and organic carbon fractions predicted from near-infrared spectroscopy and geostatistics. Soil Sci. Soc. Am. J. 81, 1222-1234.

Dikmen, S., Hansen, P.J., 2009. Is the temperature-humidity index the best indicator of heat stress in lactating dairy cows in a subtropical environment. J. Dairy Sci. 92, 109-116.

Dold, C., Thomas, A.L., Ashworth, A.J., Philip, D., Brauer, D.K., Sauer, T.J., 2019. Carbon sequestration and nitrogen uptake in a temperate silvopasture systems. Nutr Cycl Agroecosyst. 114, 85-98. https://doi.org/10.1007/s10705-019-09987-y.

Dubeux, J.C.B.Jr., Muir, J.P., de Oliveira Apolinário, V.X., de Andrade Lira, M. Sollenberger, L.E., 2017. Tree legumes: an underexploited resource in the warmclimate silvopastures. R. Bras. Zootec. 46, 608-703.

Franzluebbers, A.J., Chappell, J.C., Shi, W., Cubbage, F.W., 2017. Greenhouse gas emissions in an agroforestry system of the southeastern USA. Nutr. Cycl. Agroecosyst. 108, 85-100.

Gosme, M., Dufour, L., Inurreta-Aguirre, H.D., Dupraz, C., et al., 2016. Microclimatic effect of agroforestry on diurnal temperature cycle. In: Gosme, M. (Ed.), $3^{\text {Rd }}$ European Agroforestry Conference - Montellier, 23-25 May 2016. EURAF, pp. 183-186.

Griffin, J.L., Jung, G.A., 1983. Leaf and stem quality of big bluestem and switchgrass. Agron. J. 75, 723-726.

Hodge, G.R., Acosta, J.J., Unda, F., Woodbridge, W.C., Mansfield, S.D., 2018. Global near infrared spectroscopy models to predict wood chemical properties of Eucalyptus. J. Near Infrared Spectrosc. 26, 117-132.

Igono, M.O., Bjotvedt, G., Sandford-Crane, H.T., 1992. Environmental profile and critical temperature effects on milk production of Holstein cows in desert climate. Int. J. Biometeorol. 36, 77-87.

Jose, S., 2009. Agroforestry for ecosystem services and environmental benefits, an overview. Agroforestry Syst. 76, 1-10.

Jose, S., Dollinger, J., 2019. Silvopasture, a sustainable livestock production system. Agroforestry Syst. 93, 1-9.

Jose, S., Walter, D., Mohan Kumar, B., 2019. Ecological considerations in sustainable silvopasture design and management. Agroforestry Syst. 93, 317-331.

Karki, U., Goodman, M.S., 2013. Microclimatic differences between young long-leaf pine silvopasture and open-pasture. Agroforestry Syst. 87, 303-310.

Karki, U., Goodman, M.S., 2015. Microclimatic differences between mature loblolly-pine silvopasture and open-pasture. Agrofor. Syst. 89, 319-325.

Kendall, P.E., Nielsen, P.P., Webster, J.R., Verbek, G.A., Littlejohn, R.P., Matthews, L.R. 2006. The effects of providing shade to lactating dairy cows in a temperature climate. Livestock Sci. 103, 148-157.

Kephart, K.D., Buxton, D.R., Taylor, S.E., 1992. Growth of $\mathrm{C}_{3}$ and $\mathrm{C}_{4}$ perennial grasses under reduced irradiance. Crop Sci. 32, 1033-1038.

Keyser, P., Harper, C., Bates, G., Waller, J., Holcomb, E.D., 2015. Establishing Native Warm-season Grasses for Livestock Forage in the Mid-South. SP 731-B. University of Tennessee Available online, http, //nativegrasses.utk.edu/publications/SP731-B.pdf (Accessed 27 June 2019).

Kim, D., Kirschbaum, M.U.F., Beedy, T.L., 2016. Carbon sequestration and net emissions of $\mathrm{CH}_{4}$ and $\mathrm{N}_{2} \mathrm{O}$ under agroforestry: synthesizing available data and suggestions for future studies. Agric. Ecosyst. Environ. 226, 65-78. https://doi.org/10.1016/j.agee. 2016.04.011.

Lawson, G., Christian, D., Watté, J., et al., 2018. Can silvoarable systems maintain yield, resilience, and diversity in the face of changing environments? In: Lemaire (Ed.), Agro-Ecosystem Diversity: Impact on Food Security and Environmental Quality. Elsevier (Accessed 19 November 2019). https://www.sciencedirect.com/book/ 9780128110508/agroecosystem-diversity\#book-info.

Lin, C.H., McGraw, R.L., George, M.F., Garret, H.E., 1999. Shade effects on forage crops with potential in temperature agroforestry practices. Agroforestry Syst. 44, 109-119.

Mauricio, M.R., Ribeiro, R.S., Paciullo, D.S.C., Cangussú, M.A., Murgueitio, E., Chará, J., Estrada, M.X.F., et al., 2018. Silvopastoral systems in latin America for biodiversity, environmental, and socioeconomic improvements. In: Lemaire (Ed.), Agro-Ecosystem
Diversity: Impact on Food Security and Environmental Quality. Elsevier (Accessed 19 November 2019). https://www.sciencedirect.com/book/9780128110508/ agroecosystem-diversity\#book-info.

Misztal, I., 2017. Breeding and genetics symposium: resilience and lessons from studies in genetics of heat stress. J. Anim. Sci. 95, 1780-1787.

Mitlöhner, F.M., Morrow, J.L., Dailey, J.W., Wilson, S.C., Galyean, M.L., Miller, M.G., McGlone, J.J., 2020. Shade and water misting effects on behavior, physiology, performance, and carcass traits of heat-stressed feedlot cattle. J. Anim. Sci. 79, 2327-2335.

Nardone, A., Ronchi, B., Lacereta, N., Bernabucci, U., 2006. Climate effects on productive traits in livestock. Vet. Res. Commun. 30, 75-81.

National Research Council (NRC), 1971. A Guide to Environmental Research on Animals. Natl. Acad. Sci., Washington, DC.

National Research Council (NRC), 1996. Nutrient Requirements of Beef Cattle, 7th Ed. Natl. Acad. Press, Washington DC.

Neel, J.P.S., Feldhake, C.M., Belesky, D.P., 2007. Influence of solar radiation on the productivity and nutritive value of herbage of cool-season species of an understory sward in a mature conifer woodland. Grass Forage Sci. 63, 38-47.

Perry Jr, L.J., Baltensperger, D.D., 1979. Leaf and stem yields and forage quality of three $\mathrm{N}$-fertilized warm-season grasses. Agron. J. 71, 355-358.

Peters, M., Herrero, M., Fisher, M., Erb, K.-H., Rao, I., Subbarao, G.V., et al., 2013. Challenges and opportunities for improving eco-efficiency of tropical forage-based systems to mitigate greenhouse gas emissions. Trop. Grassl.-Forrajes Trop. 1, 156-167. https://doi.org/10.17138/TGFT(1)156-167.

Power, A.G., 2010. Ecosystem services and agriculture: tradeoffs and synergies. Philos. Trans. Biol. Sci. 365, 2959-2971.

Ravagnolo, O., Misztal, I., Hoogenboom, G., 2000. Genetic component of heat stress in dairy cattle, development of heat index function. J. Dairy Sci. 83, 2120-2125.

Richner, J.M., Kallenbach, R.L., Roberts, C.A., 2014. Dual use switchgrass: managing switchgrass for biomass production and summer forage. Agron. J. 106, 1438-1444. https://doi.org/10.2134/agronj13.0415.

Rojas-Downing, M.M., Pouyan Nejadhashemi, A., Harringan, T., Woznicki, S.A., 2017. Climate change and livestock: impacts, adaptation, and mitigation. Clim. Risk Manag. 16, 145-163. https://doi.org/10.1016/j.crm.2017.02.001.

Rosenstock, T.S., Wilkes, A., Jallo, C., Namoi, N., Bulusu, M., Suber, M., Mboi, D., Mulia, R., Simelton, E., Richards, M., Gurwick, N., Wollenberg, E., 2019. Making trees count: measurement and reporting agroforestry in the UNFCCC national communications of non-Annex I countries. Agric. Ecosyst. Environ. https://doi.org/10.1016/j.agee.2019. 106569.

Sethi, R.K., Nagarcenkar, R., 1981. Inheritance of heat tolerance in buffaloes. Ind. J. Anim. Sci. 51, 591-595.

Smith, R.S., Schwer, L., Boyd, H., Keene, T., 2012. Prechilling Switchgrass Seed on Farm to Break Dormancy. University of Kentucky Extension ID-199. http.//www2.ca.uky.edu/agcomm/pubs/id/id199/id199.pdf. (Accessed 25 October 2018).

Sollenberger, L.E., Kohmann, M.M., Dubeaux, J.C.B., Silveira, M.L., 2019. Grassland management affects delivery of regulating and supporting ecosystems services. Crop Sci. 59, 441-459.

St-Pierre, N.R., Cobanov, B., Schnitkey, G., 2003. Economic losses from heat stress by US livestock industries. J. Dairy Sci. 86, E52-E77.

Tucker, C.B., Rogers, A.R., Schütz, K.E., 2008. Effect of solar radiation on dairy cattle behaviour, use of shade and body temperature in pasture based system. Applied Anim. Behaviour Sci. 109, 141-154.

USDA, 2017. Agroforestry: Enhancing Resiliency in US Agricultural Landscapes under Changing Conditions. Gen. Tech. Report WO-96. Available online, https, //www.fs.usda.gov/treesearch/pubs/55775 (Accessed 5 August 2019). .

Verchot, L.V., van Noordwijk, M., Kandji, S.T., Tomich, T.P., Ong, C., Albrecht, A., Mackensen, J., Bantilan, C., Anupama, K.V., Palm, C.A., 2007. Climate change: linking adaptation and mitigation through agroforestry. Mitig. Adapt. Strateg. Glob. Change 12, 901-918. https://doi.org/10.1007/s11027-007-9105-6.

Villanueva, C., Casasola, F., Detlefsen, G., 2018. Potencial de los sistemas silvopastoriles en la mitigación al cambio climático y en la generación de multiples beneficios en fincas ganaderas de Costa Rica. Centro de Agricultura Tropical de Investigación y Enseñanza (CATIE). Boletín técnico \#87. Turrialba, Costa Rica Available online, http, //repositorio.bibliotecaorton.catie.ac.cr/handle/11554/8729 (Accessed July 30, 2019).

Waramit, N., Moore, K.J., Heggenstaller, A., 2011. Composition of native warm-season grasses for bioenergy production in response to nitrogen fertilization rate and harvest date. Agron. J. 103, 665-1662.

West, J.W., 2002. Effect of heat stress on production of dairy cattle. J. Dairy Sci. 86, 2131-2144. 